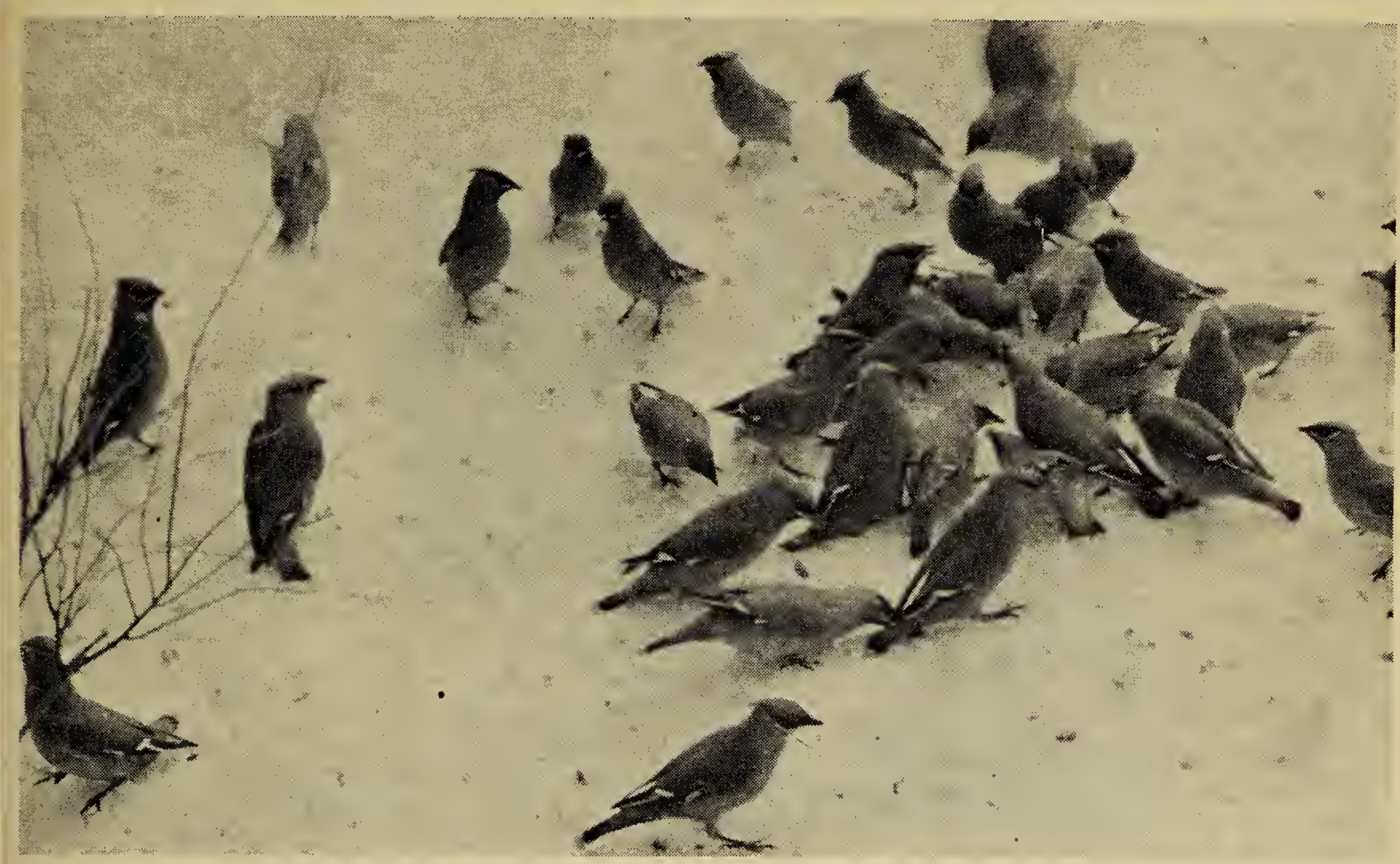

Bohemian Waxwings at Estevan, 1963.

Photo by W. G. Squires.

ing as much as 100 pounds of raisins in a week. Only through the generosity of bird lovers in Estevan and elsewhere was the feeding of these winged creatures made possible. At one time there were approximately 120 in the flock and they became so adventurcus that they would settle on a hand or a forearm held just within the window-a remarkable sight which has been recorded on ordinary black-and-white film as well as on colored $8 \mathrm{~mm}$. movie.

A yellow shoe box in which some of the raisins were kept was not long in being identified by these waxwings and its appearance at the window immediately brought swarms of them to that window. The birds were fed at fairly regular hours several times daily, and if for some reason Sister Doloretta was a bit tardy, they were not hesitant to let those around know by chattering away on the trees and also by swooping down on the window sill and pecking at the window. The feeding time varied somewhat according to the winter sunrise and sunset but it was roughly between eight and nine a.m. and four and five p.m. There were always some, however, which were not reluctant to accept food at other hours in the day and these afforded the doctors working in the hospital and some visitors the pleasure of feeding them by hand. After the last feeding in the afternoon the birds would disappear mysteriously only to return at the appointed time in the morning.

One mild day in March, Sister Doloretta manoeuvred her wheel chair to the grounds outside the hospital and near the window at which the birds were accustomed to being fed. What a thrill it must have been to her when a goodly' number of her wild friends flew down from the trees to settle in her lap and on her head!

\section{CO-OPERATIVE MIGRATION STUDY} - SPRING OF 1963

The following species are listed for observation for the spring of 1963: Whistling Swan, Canada Goose, Mallard, Pintail, Marsh Hawk, Killdeer, Common Snipe, Mourning Dove, Common Nighthawk, Chimney Swift, Ruby-throated Hummingbird, Yellow-shafted Flicker, Eastern Kingbird, Great Crested Flycatcher, Eastern Phoebe, Eastern Wood Pewee, Barn Swallow, Purple Martin, Common Crow, House Wren, Catbird, Brown Thrasher, Wood Thrush Eastern Bluebird (male), Eastern Bluebird (fem.), Red-eyed Vireo, Black-and-white Warbler, Tennessee Warbler, Yellow Warbler, Myrtle Warbler, Blackpoll Warbler, Ovenbird, American Redstart, Bobolink, Redwinged Blackbird, Baltimore Oriole, Scarlet Tanager, Rose-breasted Grosbeak, Indigo Bunting, American Goldfinch, Slate-colored Junco, Chipping Sparrow. White-crowned Sparrow, Whitethroated Sparrow.

Information will include first arrival (date, number), and if possible dates and numbers of peaks, and departure. If you have information an any of these species not yet submitted, send report by June 15, 1963, to Mrs. Dorothy Wade, 1351 Jubilee Avenue, Regina. 